\title{
The Paper Trade in Early Modern Europe: An Introduction
}

\author{
Daniel Bellingradt
}

\section{1 Introduction}

Early modern Europe was a paper age - an age of paper production, of paper usage, of paper consumption, and also of paper trading. When referring to the historiographical period of European "Early Modernity," ranging from circa 1400 to 1800 , it seems appropriate to name this timespan the first European paper age. By the time that paper was introduced and produced in Europe, first by Arab papermakers and via Arab trade contacts from the eleventh and twelfth centuries, the artefact 'paper' was already an established product known, used, and produced in China for more than 1300 years. ${ }^{1}$ Europe's first paper age may have started with trade imports but a separate way of producing paper eventually developed, starting in the early thirteenth century on the Iberian Peninsula and in Italy. ${ }^{2}$ By the fourteenth century, paper mills became an investment option within the commercial world, and with the spread of the art of making paper through Europe, paper sheets started their journey as a commonly known economic good. In fact, paper products of European origin quickly became a transregionally moved, traded, and sold good. ${ }^{3}$ In keeping

1 See for the oldest known paper, which is dated to the early and century BC:Yi Xumei, and Lu Xiuwen, 'The Calligraphy and Printing Cultural Heritage of Gansu. The Development of the Engraved Printing Process and Papermaking: an Archaeological Approach', in: Susan M. Allen etc (eds.), The History and Cultural Heritage of Chinese Calligraphy, Printing and Library Work (Berlin: De Gruyter Saur, 2010), pp. 45-70, here: p. 64.

2 See as introduction to the Asian, Arabic and European ways of making and selling paper: Dard Hunter, Papermaking Through Eighteen Centuries (New York: Rudge, 1930); Dard Hunter, Papermaking. The History and Technique of an Ancient Craft (New York: Knopf, 1947); Jonathan Bloom, Paper before Print. The History and Impact of Paper in the Islamic World (New Haven, Conn.: Yale University Press, 2001); Helen Loveday, Islamic Paper. A Study of the Ancient Craft (London: Don Baker Memorial Fund, 2001). For a lively discussion about where the first European papermakers were active see Peter F. Tschudin, 'Paper Comes to Italy', International Paper History, 12 (1998), pp. 6o-66.

3 Franz Irsigler, 'Überregionale Verflechtungen der Papierer. Migration und Technologietransfer vom 14. bis zum 17.Jahrhundert', in Knut Schulz (ed.), Handwerk in Europa. Vom Spätmittelalter 
with the broader trade mobility of the period, these early paper flows reached places and regions both with and without their own paper mills and established the first regular markets for the purchase, usage, and consumption of paper. From its earliest days in Europe, the man-made artefact paper was a hand-formed and moved economic good that was produced as a commodity to be sold. The accompanying economic activities of producing, moving, and selling paper are echoed in historiographical interpretations as the founding moments of an early paper industry. 4

The products made, moved, and sold by this industry - mainly for writing, printing and wrapping purposes - were purchased and used in growing numbers from the fourteenth century onwards. By at least the fifteenth century, paper became a good and steadily selling product in Europe, as paper was increasingly used in more and more individual and public contexts including education, administration, correspondence, arts, transport, and of course within the burgeoning printing industries in Europe. New and quickly-expanding paper usages in archiving, administrating, communicating, and wrapping activities, are legion within the historiography of early modern Europe, and in sum they tell us a history of paper as one of the main material characteristics of the period. ${ }^{5}$ From fresh writing and printing papers, to wallpapers, wrapping papers and coloured and artist's papers, from tobacco paper to playing cards, from greeting cards to newspapers, pamphlets, and broadsheets, from calendars

bis zur Frühen Neuzeit (Munich: Oldenbourg, 1999), pp. 255-276; Carla Meyer, Sandra Schultz, and Bernd Schneidmüller (eds.), Papier im mittelalterlichen Europa. Herstellung und Gebrauch (Berlin, Boston: De Gruyter, 2015); Rosella Graziaplena, 'Paper trade and diffusion in late medieval Europe. A first approach' in Rosella Graziaplena, Mark Livesey (eds.), Paper as a Medium of Cultural Heritage, Archaeology and Conservation. 26th Congress International Association of Paper Historians (Rom: ICPL, 2004), pp. 343-356; Franz Irsigler, 'La carta. Il commercio', in Simonetta Cavaciocchi (ed.), Produzione e commercio della carta e del libro, secc. XIII-XVIII (Grassina: Le Monnier, 1992), pp. 143-210; Maria Zaar-Görgens, Champagne, Bar, Lothringen. Papierproduktion und Papierabsatz vom 14. bis zum Ende des 16. Jahrhunderts (Trier: Porta-Alba-Verlag, 2004).

4 See for example: Donald C. Coleman, The British paper industry 1495-1860. A study in industrial growth (Oxford: Clarendon Press, 1958); Henk Voorn, De geschiedenis der Nederlandse papierindustrie (4 vols., Haarlem: Papierwereld, 1960-1987), I and II.

5 See the literature references on this point throughout the volume as well as in this introduction. The popularity of the topic itself, the growing and transforming paper usages in Early Modern Europe (and elsewhere), can easily be seen in the many popular science bestsellers like Lothar Müller, White Magic. The age of paper (Cambridge: Polity Press, 2014); Nicolas A. Basbanes, On Paper. The Everything of its Two-Thousand Year History (New York: Knopf, 2013); Mark Kurlansky, Paper. Paging through History (New York, London: W.W. Norton \& Company, 2016; Alexander Monro, The Paper Trail. An Unexpected History of the World's Greatest Invention (London: Lane, 2014); Michel Vernus, La fabuleuse histoire du papier (Yens-sur-Morges, Cabédita, 2004); Ian Sansom, Paper. An Elegy (London: Fourth Estate, 2012). 
to journals: a diverse plurality of papers was experienced by both literate and non-literate people alike in early modern Europe. As a hand-made economic product, paper was one of the main artefacts of the period, a mass product that came in many formats and qualities for a variety of usages. Coming up with concrete numbers of newly manufactured papers of the period (e.g. the number of sheets produced from a mould) is inherently problematic due to missing data, including where and when paper mills were run in Europe and variables in their productivity, which was often affected by such diverse conditions as harsh winters, differing local and transregional labour conditions, the availability of resources like linen rags, tax requirements and regulations, short-term and long-term purchase trends, the producers' finances, military conflicts, and many circumstances too numerous to name. Despite this, such calculations help in estimating the broader economic picture of production and paper sales within Europe. Given that, with ideal (but not realistic) conditions and starting as early as the fifteenth century, each mould could have produced about one million sheets annually - the average technically possible production is estimated by experts at about 800,000 to 900,000 sheets annually per mould. ${ }^{6}$ As working and producing practices did not change significantly between the early fourteenth and the late eighteenth centuries, this would theoretically mean: 5 sheets per minute, 300 per hour, and more than 3600 sheets per working day, according to Frieder Schmidt. ${ }^{7}$ However, more careful and moderate estimates of the productivity and mass output of these paper industries have to be taken into serious consideration, because they shed light on the potential lucrativeness of trading in paper products. For example, it is estimated that for the decades around 1700 northern Dutch paper production for only writing and printing papers comprised annually about 60 million sheets. That is 120,000 reams, each consisting of about 500 sheets per year that needed to be traded, sold, and stored before someone would use it for printing or writing purposes somewhere in the Netherlands. ${ }^{8}$ The

6 Gerhard Piccard, 'Die Wasserzeichenforschung als historische Hilfswissenschaft', Archivalische Zeitschrift, $5^{2}$ (1956), pp. 62-115, here: p. 73; Gerhard Piccard, 'Papiererzeugung und Buchdruck in Basel bis zum Beginn des 16. Jahrhunderts. Ein wirtschaftsgeschichtlicher Beitrag', Börsenblatt für den deutschen Buchhandel. Frankfurter Ausgabe, 76 (1966), pp. 18191967, here: p. 1826.

7 Frieder Schmidt, 'Spätmittelalterliches Papier als dingliches Artefakt', in Christoph Reske, and Wolfgang Schmitz (eds.), Materielle Aspekte in der Inkunabelforschung (Wiesbaden: Harrassowitz, 2017), pp. 109-120, here: p. 118.

8 Andrew Pettegree, and Arthur der Weduwen, The Bookshop of the World. Making and Trading Books in the Dutch Golden Age (New Haven, Conn.: Yale University Press, 2019), p. 396 (referring explicitly to Karel Davids, The Rise and Decline of Dutch Technological Leadership. Technology, Economy and Culture in the Netherlands, 1350-1800 (2 vols., Leiden: Brill, 2008), II. 167-171.). 
estimates for eighteenth-century northern Dutch production are even higher, and range between 200 million sheets annually (Bellingradt) and 140 million sheets annually (Voorn). ${ }^{9}$ Comparisons to the Dutch paper industries - the market leaders of their time - are sparse. In sixteenth-century France, the average technically possible annual production of paper has, in accordance to the already mentioned approaches, been estimated between 450,000 and 900,000 reams annually; even the lower figure of 450,ooo reams would still come out to be about 220 million sheets of fresh paper produced each year from French paper moulds. ${ }^{10}$ For eighteenth-century France, Warren J. Scoville estimates a daily production per mould of between $2-10$ reams, i.e. 600-300o reams per year, but as estimates of the exact numbers of active moulds are shaky, the total sum of French paper production may have been something more along the lines of 100 million sheets annually during the 1770 and 1780 os. ${ }^{11}$ But again, however patchy these calculations may be at the moment, they still deliver a strong message to economic and trade historians alike: purely by numbers, the artefact paper was among the most typical economic goods of the period. In this sense, the many metaphorical terms used to refer to the scale and impact of paper usages from the early modern period onwards have an impressive, though as of yet, mainly unreflected upon, meaning. This holds as true for the term and concepts of "paper worlds," coined within the History of Ideas and Intellectual History to describe the early modern culture of paper production, paper utilization, and of course, paper storage in libraries and in archives, ${ }^{12}$ as it does for the multitude of paper expressions and references used in many disciplines to address the typical pre-modern and modern cultural management of information and knowledge production from paper, on paper, and with paper like "paper knowledge" (Lisa Gitelman) resulting from "paperwork" (Ben Kafka) in a "paper world", "papereality" (David Dery), or "paper

9 Daniel Bellingradt, Vernetzte Papiermärkte. Einblicke in den Amsterdamer Handel mit Papier im 18. Jahrhundert (Cologne: Herbert von Halem Verlag, 2019), pp. 22-23; Voorn, De geschiedenis der Nederlandse papierindustrie, I. 74 and III. 144-145.

10 Lucien Febvre, and Henri-Jean Martin, The Coming of the Book. The Impact of Printing, 1450-180o (London: N.L.B., 1976), p. 40 work with these figures for France and refer to Antoine Vitré (Ce que les Presses qui Travaillent á Présent dans Paris consomment de Papier; Bibliotheque Nationale de France, Ms. 16746).

11 Warren J. Scoville, 'Government regulation and growth in the French paper industry during the eighteenth century', The American Economic Review, 57:2 (1967), pp. 283-293, esp. $284-285$.

12 See, on the use of the term "paper world", Bruno Latour, Science in Action. How to Follow Scientists and Engineers through Society (Cambridge, Mass.: Harvard University Press, 1987); Neil Rhodes, and Jonathan Sawday (eds.), The Renaissance Computer. Knowledge in the First Age of Print (London: Routledge, 200o). 
age" (Kevin McLaughlin), fuelled by the increasing usage of "paper machines" (Markus Krajewski). ${ }^{13}$

For this introduction and edited volume the foremost idea is to look specifically at the trade of this common economic good, 'paper.' Scholars working in many historical (sub-) disciplines have described Europe's first 'paper age', with its numerous paper mills and the later cultural uses and effects of paper-use, but without any examination of the trade of the good. At the moment, we do not have an appropriate understanding of the trading activities which underlay the many paper usages of the period. The consideration of this dilemma resulted in the 2019 conference, "The Paper Trade in Early Modern Europe: Practices, Materials, Networks," a conference that was devoted solely to making the first steps towards constructing a history of the paper trade in early modern Europe. ${ }^{14}$ The present volume grew out of the Erlangen conference, and this introduction resonates with ideas presented at the conference and in the following chapters, as well as with the questions that each raises. In a nutshell, this volume aims to find answers to the basic question: where are the (yet invisible) trading activities behind all of these visible paper relics that were once produced, moved, read, stored, used, and recycled all over Europe? The exchanges of the paper trade were a relevant, though as-of-yet largely overlooked, economic activity (as the next section of this introduction will explore further), which also functioned as the essential link between the manufacture of paper and the usage and consumption of paper products in the social worlds. This volume sets out to shed light upon this desiderata of economic history, as well as on a broad but still burgeoning history of communications. In doing so, this volume's arguments make a case for an accentuated analytical perspective on historical materiality, as well as a plea for alternative focuses in media studies, communication studies, and book studies. ${ }^{15}$ Section two of this introduction ("A paperless history of the first European paper age")

13 Markus Krajewski, Paper Machines. About Cards and Catalogs, 1548-1929 (Cambridge, Mass.: MIT Press, 2011; Lisa Gitelman, Paper Knowledge. Toward a Media History of Documents (Durham, NC: Duke University Press, 2014); Ben Kafka, 'Paperwork. The State of the Discipline', Book History, 12:1 (2009); Ben Kafka, The Demon of Writing. Powers and Failures of Paperwork (New York: Zone Books, 2012; David Dery, "Papereality" and learning in Bureaucratic Organizations', Administration and Society, $29: 6$ (1998), pp. 277-289; Kevin McLaughlin, Paperwork. Fiction and Mass Mediacy in the Paper Age (Philadelphia, Pa.: University of Pennsylvania Press, 2005).

14 Heather Wolfe, 'The Paper Trade in Early Modern Europe. Practices, Materials, Networks, 26.02.2019-27.02.2019 Erlangen' H-Soz-Kult (2019), online version: www.hsozkult.de/ conferencereport/id/tagungsberichte-8242 [last accessed: 02.05.2020].

15 See on the "alternatives left behind" in Communication Studies Peter Simonson, David W. Park, 'Introduction. On the History of Communication Study', in Peter Simonson, 
highlights the missed chances of historiography to treat paper as a trade good of historical interest. As the artefact 'paper' and its exchanges are relevant in early modern Europe, historiography must increase paper's visibility in historical approaches. Our approach in this volume is to bring paper trade history to the forefront by studying its practices, materials, and networks. The third section of the introduction, "Approaching the early modern paper trade," explains, therefore, the analytical benefits of doing so and discusses the theoretical and methodological value of the three chosen leading themes - practices, materials, and networks. The final and concluding section, "A future paper history," sets out to explore the perspectives and benefits of a future historical research into the matter.

A Paperless History of the First European Paper Age

The historiography of early modern Europe is a curiously paperless history. While Europe developed and cultivated a rich culture of paper production and consumption, historians tend to be more interested in designing the influential narrative of a "printing era," an era of marks and impressions primarily upon paper, rather than an era of paper itself. Even though it is a well-known fact within historiography that a short-term lack of paper means that no administrative records, or letters, or publications can be produced, the history of the paper trade remains one of the least studied areas of early modern history. For decades, perspectives on the trading of all paper products were lost somewhere in-between economic history, book history, communication history, and many other fields of historic expertise that encompassed paper usage and the production of paper. While paper artefacts are omnipresent and visible in our histories of early modern Europe, the paper trade is oddly invisible, or at best, well-hidden - almost as if it were a clandestine activity. As will be highlighted in detail throughout the following pages, communication history and paper history has not paid much attention to the trade of the material; economic and trade historians have lacked interest in paper and while book historians sometimes mention the connection of paper production and its selling to the world of printing, they tend to eschew the details linking these trade activities.

Traditionally, paper caught the attention of interdisciplinary studies examining the changing behaviours and practices of communications in early modern Europe. In these studies of communication history, a paper-related focus starts

and David W. Park (eds.), The International History of Communication Studies (New York: Routledge, 2016), pp. 1-22, esp. p. 3. 
with the transition from the utilization of vellum to paper for written communication and documentation, and usually relies on the growing secretarial aspects of administrative work all over Europe. ${ }^{16}$ Here, the usages of paper as the most important and common material to be written upon (e.g. to produce a new administration record), are interpreted as a "paper revolution," building on the growing availability of the material paper (from new paper mills), and an unfolding and ever-increasing written culture in diplomacy, archiving, and so on. ${ }^{17}$ These writings on paper are described as a "paper technology" or as "paper work,"18 while the overall paper-based archival and informational practices of the period are characterized as the record-keeping business of so called "paper states."19 It is this epoch's formation of bureaucracies and the practice of scholarly record-keeping that historians generally address as a paper-based knowledge creation, connected to the birth of (paper) archives, and to information handling tendencies, and knowledge production in general. ${ }^{20}$ These

16 See on this transition: Paul Needham, 'Book Production on Paper and Vellum in the fourteenth and fifteenth centuries' and Franz-Josef Arlinghaus 'Materialität und Differenzierung der Kommunikation. Zu Funktionen des Pergament-und Papiergebrauchs in der spätmittelalterlichen Ständegesellschaft', in Meyer, Schultz, Schneidmüller, Papier im mittelalterlichen Europa, pp. 247-274, and pp. 179-19o.

17 Robert I. Burns, 'The Paper Revolution in Europe. Crusader Valencia's Paper Industry', Pacific Historical Review, 50 (1981), pp. 1-30; Sandra Schultz, Papierherstellung im deutschen Südwesten. Ein neues Gewerbe im späten Mittelalter (Berlin: De Gruyter, 2018).

18 Elizabeth Yale, 'The History of Archives. The State of the Discipline', Book History, 18:1 (2015), pp. 332-359, here: p. 355. On the use of the term "paper technology" see Aileen Douglas, Work in Hand. Script, Print, and Writing, 1690-1840 (Oxford: Oxford University Press, 2017); Anke te Heesen, 'The Notebook. A Paper-Technology', in Bruno Latour, and Peter Weiber (eds.), Making Things Public, Atmospheres of Democracy (Cambridge, Mass.: MIT Press, 2005), pp. 582-89.

19 See as introduction to these fields: Paul M. Dover (ed.), Secretaries and Statecraft in the Early Modern World (Edinburgh: Edinburgh University Press, 2016); Jacob Soll, The Information Master. Jean-Baptiste Colbert's Secret State Intelligence System (Ann Arbor, Mich.: University of Michigan Press, 2009); Randolph C. Head, 'Configuring European Archives. Spaces, Materials and Practices in the Differentiation of Repositories from the Late Middle Ages to 1700', European History Quarterly, 46:3 (2016), pp. 498-518; Markus Friedrich, The Birth of the Archive. A History of Knowledge (Ann Arbor, Mich.: University of Michigan Press, 2018); Filippo de Vivo, A. Guidi, and A. Silvestri (eds.), Archivi e archivisti in Italia tra Medioevo e età moderna (Rome: Viella, 2015); Arndt Brendecke, Imperium und Empirie. Funktionen des Wissens in der spanischen Kolonialherrschaft (Cologne: Böhlau, 2009); Sylvia Sellers-García, Distance and Documents at the Spanish Empire`s Periphery (Stanford, Cal., Stanford University Press, 2014); John C. Rule, and Ben S. Trotter, A World of Paper. Louis XIV, Colbert de Torcy, and the Rise of the Information State (Montreal: McGill-Queens University Press, 2014).

20 Vgl. Arndt Brendecke, Markus Friedrich, and Susanne Friedrich (eds.), Information in der Frühen Neuzeit. Status, Bestände, Strategien (Berlin: Lit, 20o8); Stefan Haas, and Mark 
schools of ideas and perspectives are echoed especially in media studies where a media history of documents ${ }^{21}$ is being developed - a theory based around the cultural usages of paper-related and paper-based data documentation.

In these worlds of paper consumption and paper storage within newly created archives, paper is a resource awaiting use, one that had to be purchased somehow and somewhere. In a single sentence: the ever-used and ever-needed material, paper, is simply waiting to be written upon. Paper is, in this sense, an anticipatory resource that is then, by the act of being written upon, enriched with important and sometimes genius intellectual creativity by the writer. ${ }^{22} \mathrm{Of}$ course, every secretary, every archive, and every writer had to purchase paper on a regular basis before the writing process could commence. Despite this, only a few scholars address this purchase as a necessary and regular practice connected to the act of writing. In fact, Megan Williams, who also contributes to this volume, is one of the few voices addressing in detail the importance of routine paper-purchases. ${ }^{23}$ Williams argues that the purchase of paper has to be included and reflected upon when dealing with the "paper practices" of European early modernity. In summation, the communication histories that tackle an increase in paper usage ought to also be extended to include

Hengerer (eds.), Im Schatten der Macht. Kommunikationskulturen in Politikund Verwaltung 1600-1950 (Frankfurt a.M.: Campus-Verlag, 2008); Alberto Cevolini (ed.), Forgetting Machines. Knowledge Management Evolution in Early Modern Europe (Leiden: Brill, 2016); Liesbeth Corens, Kate Peters, and Alexandra Walsham (eds.), The Social History of the Archive. Record-Keeping in Early Modern Europe (Oxford: Oxford University Press, 2016); Liesbeth Corens, Kate Peters, and Alexandra Walsham (eds.), Archives \& Information in the Early Modern World (Oxford: Oxford University Press, 2018).

21 See especially Gitelman, Paper Knowledge and Dery “'Papereality"', pp. 277-289.

22 Christoph Hoffmann, 'Processes on Paper. Writing Procedures as Non-Material Research Devices', Science in Context, 26:2 (2013), pp. 279-303; Hans-Jörg Rheinberger, 'Scrips and Scribbles', Modern Language Notes, 118:3 (2003), pp. 622-636; James Daybell, The Material Letter in Early Modern England. Manuscript Letters and the Culture and Practices of Letter-Writing, 1512-1635 (Houndmills: Palgrave Macmillan, 2012). On the cultural impact of knowledge production see especially Lorraine Daston (ed.), Things that Talk. Object Lessons from Art and Science (New York. Zone Books, 2004); Ann Blair, Too Much to Know. Managing Scholarly Information before the Modern Age (New Haven, Conn.: Yale University Press, 2010); Pamela H. Smith, Amy Meyers, and Harold Cook (eds.), Ways of Making and Knowing. The Material Culture of Empirical Knowledge (Ann Arbor, Mich.: University of Michigan Press, 2014).

23 Megan Williams, 'Unfolding Diplomatic Paper and Paper Practices in Early Modern Chancellery Archives', in Arndt Brendecke (ed.), Praktiken der Frühen Neuzeit. Akteure, Handlungen, Artefakte (Köln: Böhlau, 2015), pp. 496-508; Megan Williams, “'Zu Notdurfft der Schreiberey." Die Einrichtung der frühneuzeitlichen Kanzlei', in Dagmar Freist (ed.), Diskurse, Körper, Artefakte. Historische Praxeologie in der Frühneuzeitforschung (Bielefeld: Transcript-Verlag, 2015), pp. 335-372. 
viewpoints on the purchase of paper. Mark Bland summarises this blind spot, writing, "we need to know how much paper was used for private, educational, ecclesiastical, business, official and secretarial purposes". ${ }^{24}$ Moreover, Bland pleas to overcome this paper-reduced path of interpretation by highlighting the many places and usages of writing upon paper: "[A]llowance must be made for the grammar schools, the universities, the Inns of Court, the Crown and Parliament, the court, personal political papers, local political administration, literary, scientific and antiquarian accounts, the law courts and the legal system, the parish churches and the central ecclesiastical administration, the guild organizations, commercial activity and bills of exchange, estate and household records, conveyancing and legal records, surreptitious material, street literature and other forms of ephemera as well as blank commonplace books, personal correspondence, drawings and private manuscript circulation." ${ }^{25}$ If we keep in mind that all such paper usages of a written culture required a steady paper supply, the purchase of paper, and a person from whom to buy the material, then we see the (yet missing) importance of administrative paper supply from trading activities. What ought to be highlighted in more detail by approaches to communication history are basic questions like, 'where did the paper come from before storage or usage?' and 'who sold paper to whom, and under what conditions?'

Book history of early modern Europe - in all its national tendencies and specializations like the French histoire du livre, the Spanish historia del libro, the Dutch boekgeschiedenis, or the German Buchgeschichte - may be an interdisciplinary field of much interest and it is certainly a field in which paper is evidently present. This is unsurprising, as from no later than the fifteenth centuries, almost all technically produced artefacts of the bookish world were paper products. As the printing industries were literally running on paper, and the supply of this "vital material" (Leon Voet) was crucial for every printer and publisher in Europe. The paper focus, and the resulting neglect of a focus upon parchment from medieval book history, is a main feature of this field. ${ }^{26}$ It is commonly agreed and discussed that there is a vital connection between the growing paper production of the period and the development of paper-run

24 Mark Bland, 'The London Book Trade in 16oo', in David Scott Kastan (ed.), A Companion to Shakespeare (Oxford: Blackwell, 1999), pp. 450-463, here: p. 46o.

25 Bland, 'The London Book Trade in 16oo', p. 46o.

26 According to Leon Voet, paper was the "vital material" of the publishing business. Léon Voet, The Golden Compasses. A History and Evaluation of the Printing and Publishing Activities of the Officina Plantiniana at Antwerp (2 vols., Amsterdam: Vangendt, 19691972), II., chapter “Paper and Parchment", II. 19-46, here: II. 43. 
print industries. ${ }^{27}$ Because " $[\mathrm{P}]$ aper can be viewed as a bulk commodity linking the paper trade with the book trade," as John Bidwell put it, ${ }^{28}$ book historians concerned with the "first print age" of Europe seem to have internalized that paper has a relationship to books. ${ }^{29}$ "What we call the printing 'industry," Lucien Febvre and Henri-Jean Martin stated, "was in origin an artisan's trade dependent on one primary material without which it would have been impossible, namely paper."30 Robert Darnton, often referred to as the progenitor of the field, addressed this economic relationship succinctly. For Darnton, viewpoints on the purchase and trade of paper help to make up key "economic conditions" of the highlighted book trade activities. ${ }^{31}$ Leslie Howsam paraphrased the entire interdisciplinary field succinctly, saying, "The history of the book is a way of thinking about how people have given material form to knowledge and stories," reflecting and addressing the lacking material focus of the field. ${ }^{32}$ In line with this material focus, book history of early modern Europe stresses the impact and production of print, and has distinguished it from parchment and handwriting during the middle ages. ${ }^{33}$ However, and despite all the paper-evidence in book history, from, for example, newspapers to almanacs, and broadsheets to encyclopaedias, there is as of yet no history of the early modern "business of books" (as James Raven termed it) 34 that properly includes the commodity 'paper.' Manifestly, there is yet no lemma "paper trade", and no equivalent content on the trade of paper in other lemmas, in all of the varieties of handbooks, lexicons, and guides to book history (and media

27 David Landau, and Peter Parshall, The Renaissance Print, 1470-1550 (New Haven, Conn.: Yale University Press, 1994), esp. pp. 15-16.

28 John Bidwell, 'The Study of Paper as Evidence, Artefact, and Commodity', in Peter Davison (ed.), The Book Encompassed. Studies in Twentieth-Century Bibliography (Cambridge: Cambridge University Press 1992), p. 70.

29 Vgl. exemplarisch: R.H. Clapperton, Paper and Its Relationship to Books (London: J.M. Dent, 1934); Allan Stevenson, 'Paper as bibliographical evidence', The Library, 5:17 (1962), pp. 197-212.

30 Febvre, Martin, The Coming of the Book, p. 30.

31 Robert Darnton, "What is the History of Books?" Revisited', Modern Intellectual History, 4 (2007), p. 508: "Were economic conditions more important than the formal rules imposed by political authorities? I am inclined to think so."

32 Leslie Howsam, 'The study of Book History', in Leslie Howsam (ed.), The Cambridge Companion to the History to the Book (Cambridge: Cambridge University, 2015), pp. 1-10, here: p. 1.

33 See exemplary: Frédéric Barbier, L'Europe de Gutenberg. Le livre et l'invention de la modernité occidentale (XIII ${ }^{e}-X V I^{e}$ siècle) (Paris: Belin, 2006).

34 James Raven, The Business of Books. Booksellers and the English Book Trade, 1450-1850 (New Haven, Conn.: Yale University Press, 2007). 
history in general). ${ }^{35}$ The paper trade is rarely even mentioned as a desiderata of book history, as it is in the Guide to Early Printed Books and Manuscripts ("Much archival work on the early paper trade remains to be done"). ${ }^{36}$ Too often when the materiality of texts and images is addressed, as for example recently by Adam Smyth, the focus lies strikingly on the available paper and potential printings on it. ${ }^{37}$

In fact, current book history is too often limited to perspectives and topics dealing with available paper. Traditionally, book history had a bibliographical interest in the material paper, ${ }^{38}$ but this interest was not really concerned with where paper came from, who moved it, or who sold it. Another point one finds often is the concern about the price of (available) paper when it comes to planning a print run. Generally, book historians follow the assumption that "paper was watched carefully," as C.E. Harline put it, because, according to Andrew Pettegree, "paper had to be purchased;" paper was a required resource. ${ }^{39}$ In fact, paper was the single most expensive material needed for a print production, and the most costly item for nearly every publication. Paper "used up vast amounts of capital with remorseless regularity," as Leon Voet summarised the typical paper demand of an early modern print shop. 40 "It is well known," Andrew Pettegree assists, "that in the sixteenth century the price of

35 Exemplary on either the non-existent entry "paper trade" or the lack of mention about this topic: Simon Eliot, and Jonathan Rose (eds.), A Companion to the history of the book (Malden, Mass.: Blackwell, 2007); Michael F. Suarez, and H.R. Woudhuysen (eds.), The Oxford Companion to the Book (2 vols., Oxford: Oxford University Press, 2010); John Feather (ed.), A Dictionary of Book History (London: Routledge, 1988); Ursula Rautenberg (ed.), Reclams Sachlexikon des Buches. Von den Handschrift zum E-Book, 3rd ed. (Stuttgart: Reclam, 2015); Helmut Hiller, and Stephan Füssel (eds.), Wörterbuch des Buches (Frankfurt a.M.: Klostermann, 2006); Roger Chartier, and Henri-Jean Martin (eds.), Histoire de l'édition française (4 vols., Paris: Fayard, 1985-1991), I and III; Marco Santoro, Storia del libro italiana. Libro e società in Italia dal Quattrocento al nuovo millennio (Milan: Editrice Bibliografica, 2008); Palle Birkelund (eds.) Nordisk Leksikon for Bogvcesen (2 vols., Copenhagen: Busck, 1951-1962), I.

36 Mark Bland, A Guide of Early Printed Books and Manuscripts (Chichester: Wiley-Blackwell, 2010), p. 29.

37 Adam Smyth, Material Texts in Early Modern England (Cambridge: Cambridge University Press, 2018)

38 On the tradition of treating paper seriously in bibliography see: G.Thomas Tanselle, 'The Bibliographical Description of Paper', Studies in Bibliography, 24 (1971). See for the historic approaches of Bibliography into paper history Bland, A Guide of Early Printed Books and Manuscripts, pp. 22-48; Bidwell, 'The Study of Paper as Evidence'.

39 Craig E. Harline, Pamphlets, Printing, and Political Culture in the Early Dutch Republic (Dordrecht: Springer Netherlands, 1987), p. 95; Andrew Pettegree, The French Book and the European Book World (Leiden: Brill, 2007), p. 130.

Voet, The Golden Compasses, II., chapter “Paper and Parchment," II. 19-46, here: II. 19. 
paper represented the main part of cost of a book." ${ }^{n 1}$ For the fifteenth and sixteenth centuries, estimates between $5^{\mathrm{O}-70}$ percent of the total costs of a print production are used and repeated in historical book studies. ${ }^{42}$ For the seventeenth century, 40-50 percent are calculated for books of about 1500 pages each in quarto; ${ }^{43}$ and for the eighteenth century this 50 percent estimate is still the magic number. ${ }^{44}$ Only for newspapers and magazines of the eighteenth century, which used cheap papers, estimates of about 20 percent are used. ${ }^{45}$ This costly paper then, somehow, appears in the workflows of early modern printshops without further notice or reference. ${ }^{46}$ This line of interpretation, in which paper is waiting somewhere until the printing process starts, derives clearly from the early modern manuals on the art of printing. Here, invisible hands have taken care of the purchase of the resource paper, and the real hands start to work in the printshop when this paper was ready to be used. At best, book historians mention the necessity of purchasing "with care" when paper was needed. Exemplary: "It can be assumed therefore in principle ... that a printer planned his paper purchases with care and exhausted one

41 Pettegree, The French Book, p. 13 o.

42 See exemplary Neil Harris, Paper and Watermarks as Bibliographical Evidence, 2nd ed. (Lyon: Institut d'Histoire du Livre, 2017), p. 136.

43 David McKitterick, A History of Cambridge University Press (3 vols., Cambridge: Cambridge University Press, 1992-2004), I. 285.

44 See Darnton, “'What is the history of books?"', pp. 495-508, esp. p. 497; Patricia Hernlund, 'William Strahan's Ledgers, II. Charges for Paper $1738-1785$, Studies in Bibliography, 22 (1969), pp. 179-195; Karl Tilman Winkler, Handwerk und Markt. Druckerhandwerk, Vertriebswesen und Tagesschrifttum in London 1695-1750 (Stuttgart: Steiner, 1993), esp. pp. 299-307; John Bidwell, 'The Industrialization of the Paper Trade', in M. F. Suarez, M. L. Turner (eds.), The Cambridge History of the Book in Britain V: 1695-1830, (Cambridge: Cambridge University Press, 2009), pp. 200-217, esp. pp. 214-215.

45 Marie-Kristin Hauke, 'Die Kunst des Klimperns. Buchhändlerische Werbestrategie und die Kommerzialisierung des Buchmarktes am Ende des 18.Jahrhunderts', Das achtzehnte Jahrhundert, 32:2 (2008), pp. 226-239, esp. p. 237; Winkler, Handwerk und Markt, pp. 299-307.

46 See on this topic, the focus on workflows with available paper, developed by Donald F. McKenzie ('Printers of the Mind. Some Notes on Bibliographical Theories and PrintingHouse Practices', Studies in Bibliography, 22 (1969), pp. 1-75); Martyn Ould, 'The Workplace. Places, Procedures, and Personnel 1668-1780', in Ian Gadd (ed.), The History of Oxford University Press I. Beginnings to 1780 (Oxford: Oxford University Press, 2013), pp. 193-240. The workflows themselves and the practices in a printers' workshop are inherent in printers' manuals of early modern Europe, see for example Joseph Moxon, Mechanik exercises, or, The doctrine of handy-works (London: J. Moxon, 1694); Christian Friedrich Gessner, Der in der Buchdruckerei wohl unterrichtete Lehr-Junge. Oder: bey der Löblichen Buchdruckerkunst Nöthige und nüzliche Anfangsgründe (Leipzig: Geßner, 1743). 
stock almost in its entirety before acquiring another." ${ }^{27}$ To be fair, this careful attention to purchasing paper for a printshop has been mentioned regularly in studies around the topic of running a print shop in the period. ${ }^{48}$ However, in general it seems that in these stories paper is waiting somewhere to be purchased, and has the tendency to appear miraculously when it is needed or ordered. Only recently, the book historian Angela Nuovo reminded the field of this long-time missing perspective, "the history of book production is also the history of paper production ... and we have little sense of the dynamics and organization of the paper industry, with all its operators and intermediaries who were the printers' usual interlocutors." 49

Within paper history however, the paper industry, as well as its dynamics and organizations, is usually described by solely focusing on the complexities of the material's manufacture. In highlighting the complexities of this craft, and especially concerning the changing techniques of production and production management, knowledge of an impressive cosmos of paper mills, watermarks,

47 Harris, Paper and Watermarks as Bibliographical Evidence, p. 136.

48 See exemplary:Frieder Schmidt, 'Die internationale Papierversorgung der Buchproduktion im deutschsprachigen Gebiet vornehmlich während des 18. Jahrhunderts', Paper History, 10:1 (2000), pp. 2-24; Annie Parent, Les Métiers du livre à Paris au XVIe siècle (1535-1560) (Geneva: Droz, 1974); Anu Lepp, 'The first year of the Academia Gustaviana print shop as seen through the history of paper', Ajalooline Ajakiri, 147 (2014), pp. 85-114; Lore Sporhan-Krempel, 'Die Papierrechnungen von Johann Friedrich Cotta 1788-1806', Archiv für Geschichte des Buchwesens, 5 (1964), col. 1370-1471; James A. Riddell, 'The Concluding Pages of the Jonson Folio of 1616', Studies in Bibliography, 47 (1994), pp. 147-154; Wolfgang Schellmann, 'Das Kontobuch der Lüneburger Offizin der Sterne. Eine Quelle neuer Erkenntnisse über Ökonomie und Usancen im Buchgewerbe des 17. Jahrhunderts', Archiv für Geschichte des Buchwesens, 68 (2013), pp. 47-103; Voet, The Golden Compasses, II. 19-46; Jacques Rychner, 'Running a Printing House in Eighteenth-Century Switzerland. The Workshop of the Société Typographique de Neuchâtel', The Library VI Series, 1:1 (1979), pp. 1-24; Hernlund, 'William Strahan's Ledgers'; I.H. van Eeghen, De Amsterdamse Boekhandel, 1680-1725 (5 vols., Amsterdam: Scheltema \& Holkema, 196o-1978), esp. IV. 195-271; Martyn Ould, Printing at the University Press, 1660-1780 I. Resources. Premises, People, \& Paper (Seaton: The Old School Press, 2015); Maurits Sabbe, 'Der Amsterdamer Papierhändler Vincent und die Antwerpener Drucker Moretus-Plantin', Gutenberg-Jahrbuch, 13 (1938), pp. 17-24; Kevin M. Stevens, and Paul F. Gehl, 'Giovanni Battista Bosso and the Paper Trade in Late Sixteenth-Century Milan', La Bibliofilia, 96:1 (1994), pp. 43-90.

49 Angela Nuovo, The book trade in the Italian Renaissance (Leiden: Brill, 2013), p. 140. See further on this claim: James Raven, Publishing Business in Eighteenth-Century England (Woodbridge: Boydell Press, 2014), pp. 63-70; I.H. van Eeghen, 'De boekhandel van de Republiek 1572-1795', in van Eeghen, De Amsterdamse Boekhandel, v. 11-128, here: v. 34-39; Th. Laurentius, 'Paper (including production, watermarks, paper trade)' in Marieke van Delft, and Clemens de Wolf (eds.), Bibliopolis. History of the printed book in the Netherlends. (Zwolle: Waanders, 2003), pp. 62-64 and pp. 113-114. 
and paper sizes was created, and continues to be created within a lively scholarly community..$^{50}$ But these research activities have become academically and scholarly isolated over the last decades; ${ }^{51}$ the result is a technology-focused auxiliary sub-discipline that, at best, mentions that paper is of course sold after production. John Bidwell summarized this trend splendidly, "These histories of papermaking are no more concerned with the marketing and sale of paper than those that take the old-fashioned, arts-and-crafts approach. Paper was meant to be sold, they concede, yet once it becomes a commodity it seems as if it had suddenly left their realm of technology and entered a foreign territory best explored by others". ${ }^{2}$ Pleas from inside the community that call for a more intensive focus on aspects of trade, like the ones Gerhard Piccard published, are ignored and largely unimitated within current research by paper historians. ${ }^{53}$ However isolated and single-focused, the economic process of making paper in an age of hand-made paper became clearer and its typical features and dynamics took shape: paper mills needed skilled specialists to work efficiently (or at all), and manufacturing paper was a business that required substantial capital. Between the fourteenth and nineteenth century,

50 See especially Hunter, Papermaking; Peter F. Tschudin, Grundzüge der Papiergeschichte, 2nd ed. (Stuttgart: Hiersemann, 2012; Harris, Paper and Watermarks as Bibliographical Evidence; Timothy Barrett, European Hand Papermaking. Traditions, Tools, and Techniques (Ann Arbor, Mich.: The Legacy Press, 2018); Schultz, Papierherstellung im deutschen Südwesten, esp. pp. 19-170. See also: Die Deutsche Bibliothek (ed.), Internationale Bibliographie zur Papiergeschichte (4 vols., Munich: Sauer, 2003) (further for studies printed after 1996 see the online-edition: http://www.memoryofpaper.eu:8o8o/ BernsteinPortal/appl_start.disp) and the periodical of the International Association of Paper Historians IPH Paper History.

$5^{1}$ See on this Schultz, Papierherstellung im deutschen Südwesten, esp. pp. 4-9; René Teygeler (ed.), Papiergeschichte als Hilfswissenschaft (Marburg/Lahn: IPH Secretary, 1996).

$5^{2}$ Bidwell, 'The Study Of Paper as Evidence', p. 78.

53 Gerhard Piccard, Frankfurt, frühe Stadt des Papierhandels (Frankfurt a.M.: Private Print, 1954), esp. p. 3. To mention the most important exceptions: Graziaplena, 'Paper Trade as a Medium and Diffusion in Late Medieval Europe'; Nils J. Lindberg, Paper comes to the North. Sources and Trade Routes of Paper in the Baltic Sea Region 1350-1700 (Marburg/ Lahn: IPH 1998); Lepp, 'The first year of the Academia Gustaviana print shop'; Viktor Thiel, 'Papiererzeugung und Papierhandel vornehmlich in den deutschen Landen von den ältesten Zeiten bis zum Beginn des 19. Jahrhunderts', Archivalische Zeitschrift, 41 (1932), pp. 106-151; Bidwell, 'The Industrialization of the Paper Trade'; F.H. Meyer, 'Papierfabrikation und Papierhandel. Beiträge zu ihrer Geschichte, besonders in Sachsen', Archiv für Geschichte des Deutschen Buchhandels, 11 (1888), pp. 283-357; Schmidt, 'Die internationale Papierversorgung'; Daniel Bellingradt, 'Trading paper in Early Modern Europe. On Distribution Logistics, Traders, and Trade Volumes between Amsterdam and Hamburg in the Mid-Late-Eighteenth Century', Jaarboek voor Nederlandse Boekgeschiedenis, 21 (2014), pp. 117-131. 
the resources, technology, financial investment, and skills needed to produce paper did not change significantly in Europe.${ }^{54}$ Moreover, for about 6 oo years, the product 'paper' was an artefact that was produced by using flax rags (alternatively, hemp rags), water and gelatine. ${ }^{55}$ Making paper was a process of transforming plant material into a sheet of paper. Because the textile industry also transformed plant materials into new products, it was thus always nearby and connected to paper manufacture, as has been stressed by paper historians very recently. .5

While an economic history of early modern Europe is slowly developing perspectives on typical economic commodities and activities, the commodity paper has not yet been positioned or addressed within the early modern 'world of commerce' by trade historians, commercial historians, nor by economic historians. ${ }^{57}$ This finding has been emphasized prominently by John Bidwell. ${ }^{58}$ All of Bidwell's sobering findings have been summed up and echoed in the only two research reviews about the state of paper (trade) history in pre-modern Europe, written by Franz Irsigler and Sandra Zawrel. Navigating this lack of

54 See on this the eighteenth-century encyclopaedic entries on the technology of paper making: Ephraim Chambers: Cyclopaedia, or, An Universal Dictionary of Arts and Sciences, 4th ed. (2 vols., London: Printed for D. Midwinter, 1741); Louis de Jaucourt, 'Papier', in:Denis Diderot, and Jean-Baptiste le Rond d'Alembert (eds.), Encyclopédie ou Dictionnaire raisonné des sciences, des arts et des métiers XI (Neuchâtel: Faulche, 1765), pp. 846-859.

55 See in detail: Schultz, Papierherstellung im deutschen Südwesten, pp. 53-170; Barrett, European Hand Papermaking; Tschudin, Grundzüge der Papiergeschichte, esp. pp. 101-202.

56 See on Europe's hemp and flax production since 1200: Katrin Kania, Kleidung im Mittelalter. Materialien, Konstruktion, Nähtechnik. Ein Handbuch (Cologne: Böhlau, 2010), esp. pp. 31-37. Especially on the material connections of paper and textiles: Joshua Calhoun, The Nature of the Page. Poetry, Papermaking, and the Ecology of Texts in Renaissance England (Philadelphia: University of Pennsylvania Press, 2020); Jonathan Senchyne, The Intimacy of Paper in Early and Nineteenth-Century American Literature (Amherst: University of Massachusetts Press, 2019).

57 See exemplarily: Paolo Malanima, Pre-Modern European Economy. One Thousand Years (1oth-19th Centuries) (Leiden: Brill, 20o9); Stephen N. Broadberry, and Kevin O'Rourke (eds.), The Cambridge Economic History of Modern Europe (2 vols., Cambridge: Cambridge University Press, 2010), I.; Geoffrey Jones, and Jonathan Zeitlin (eds.), The Oxford Handbook of Business History (Oxford: Oxford University Press, 2007); Karl Gunnar Persson, An Economic History of Europe. Knowledge, Institutions and Growth, 6oo to the Present (Cambridge: Cambridge University Press, 2010); Carlo M. Cipolla, Before the Industrial Revolution. European Society and Economy, 1000-1700 (New York: Norton, 1976). A useful overview to the existing grand narratives of Premodern Economic History offers Ulla Kypta, Julia Bruch, and Tanja Skambraks (eds.), Methods in Premodern Economic History. Case studies from the Holy Roman Empire, c.1300-c.16oo (Cham: Palgrave, 2019).

$5^{8}$ See on this the perspective from the paper historian Bidwell, 'The Study of Paper as Evidence'. 
information while tracing the ephemera of traded paper, Zawrel stresses that a paper trade perspective ought to take shape in the future, and Franz Irsigler concludes by labelling his intended research review of the medieval and early modern paper trade as a documentation of research gaps. ${ }^{59}$ Assuming that the trading activities this edited volume is devoted to were amongst the essential business enterprises of early modern European culture, this blank space overlooked by economic historians is remarkable. Even the recent plea that the good 'paper' is a useful part of a to be written transnational commercial history of pre-modern Europe derives from a group of paper historians tracking the trade flows of European paper to Africa. ${ }^{60}$

\section{$3 \quad$ Approaching the Early Modern Paper Trade}

As we know little to nothing about how the paper trade transpired, we are deeply in need of insights into actual trade practices. Such a focus will be helpful in making the many historical paper flows more visible. Highlighting these practices opens the door to addressing the social and business activities of the trade's participants. Describing these practices (which include, for example, the transporting, collecting, storing, and of course the selling of papers and its material resources) is an actor- and praxis-orientated approach to human involvement in trade activities that make up in sum the 'paper trade'. On a very basic level, approaching the practices of the paper trade requires consideration of all human involvement in the processes of the paper industry. Such an encompassing of the sociality of an economic field of activity has a rich and fruitful tradition in many fields, as can be seen for example in the history of the book trade of early modern Europe. ${ }^{61}$ Within the history of the book, this social orientation towards all involved 'book people,' or gens $d u$ livre, helped establish a broader understanding and investigation of the many shadowy but interconnected economic practices from the production levels

59 Irsigler, 'La carta. Il commercio', p. 143. Sandra Zawrel, 'Papierhandel im Europa der Frühen Neuzeit. Ein Forschungsbericht', Jahrbuch für Kommunikationsgeschichte, 19 (2017), pp. 98-120.

6o Anne Regourd (ed.), The Trade in Papers Marked with Non-Latin Characters. Documents and History (Leiden: Brill 2018).

61 See on the sociality perspective with more references: Daniel Bellingradt, and Jeroen Salman, 'Books and Book History in Motion. Materiality, Sociality and Spatiality', in Daniel Bellingradt, Paul Nelles, and Jeroen Salman (eds.), Books in Motion in Early Modern Europe. Beyond Production, Circulation and Consumption (Cham: Palgrave Macmillan, 2017), pp. 1-11. 
to the worlds of book consumption. ${ }^{62}$ For paper history, a focus on practices may lead to an identifying step that makes visible specialist actors of the paper trade: 'paper people, so to say. By describing the business practices of a paper trader or paper merchant in detail, a spotlight on predominantly unknown usages of the paper trade is established, and an overall dynamic interpretation of unknown economic activities is to be expected. For example, the common practice of many paper-sellers and paper-traders of purchasing and reselling waste paper as fresh "new" paper products, is a business tactic that has recently been brought back to light because the practices of these actors were investigated. ${ }^{63}$ Unknown organizational patterns of the paper trade also became visible: namely dealings with raw materials for future paper manufacture, and complex buyer and seller relationships with paper manufacturer and print workshop owners alike. ${ }^{64}$ It was the close examination of the practices of the involved actors that guided the interrelationship patterns from the paper mills to the various places of storing and reselling. Moreover, and more generally, a focus on practices allows us to ask, how did the paper trade function in detail? In this sense, a newly accentuated paper trade history that aims for a better understanding of the range of activities of the involved actors, establishes - via its focus on practices - theoretical interconnections to recent trends in economic history and commercial history alike. Here, actor-led perspectives on the practices of a commercial activity are seen as a key feature to access and make sense of economic networking activities of the pre-modern period. ${ }^{65}$

62 See exemplary: Hans-Jörg Künast, "Getruckt zu Augspurg”. Buchdruck und Buchhandel in Augsburg zwischen 1468 und 1555 (Tübingen: Niemeyer, 1997); Thierry Rigogne, Between State and Market. Printing and Bookselling in Eighteenth Century France (Oxford: Voltaire Foundation, 2007); Lotte Hellinga etc (eds.), The Bookshop of the World. The Role of the Low Countries in the Book Trade 1473-1941 ('t Goy-Houten: HES \& de Graaf, 2001); Roger Chartier, and Hans-Jürgen Lüsebrink (eds.), Colportage et lecture populaire. Imprimés de large circulation en Europe XVI ${ }^{\mathrm{e}}-\mathrm{XIX}{ }^{\mathrm{e}}$ siècles (Paris: IMEC Éditions,1996).

63 Daniel Bellingradt, 'Paper Networks and the Book-Industry. The Business Activities of an Eighteenth-century Paper Dealer in Amsterdam'. in Bellingradt, Nelles, Salman, Books in Motion, pp. 67-85; Bellingradt, Vernetzte Papiermärkte, pp. 153-169.

64 Bellingradt, 'Paper Networks'; Bellingradt, Vernetzte Papiermärkte, pp. 153-169.

65 Andreas Gestrich, and Margrit Schulte Beerbühl (eds.), Cosmopolitan Networks in Commerce and Society, 1660-1914 (London: German Historical Institute, 2011); Bruno Blondé etc (eds.), Buyers \& Sellers. Retail Circuits and Practices in Medieval and Early Modern Europe (Turnhout: Brepols, 2006); Mark Häberlein, and Christof Jeggle (eds.), Praktiken des Handels. Geschäfte und soziale Beziehungen europäischer Kaufleute in Mittelalter und früher Neuzeit (Konstanz: UVK Verlagsgesellschaft, 2010); Anthony Molho, and Diogo Ramada Curto, 'Les réseaux marchands à l'époque moderne', Annales. Histoire, Sciences Sociales, 58:3 (2003), pp. 569-579; Margrit Schulte Beerbühl, and Jörg Vögele 
Another benefit for paper trade history is a nuanced material focus. Just as recent research on early modern objects and their material contexts has shown, a focus on the man-made artefact 'paper' as a trading good with its own stories to tell might be enriching. ${ }^{66}$ While integrating material culture into various historiographical working methods, debates about the potential of this renewed interest started recently and are still thriving amongst historians. In this sense, paper history can contribute and engage with other historiographical trends. On the other side, continuing to ignore paper as one of the "taken-for-granted materialities" of history, as John Nerone has put it, ${ }^{67}$ is not and would not be helpful. To begin with, materiality as a theme opens a renewed discussion of the plurality of paper products and raw materials traded on the early modern markets for paper. It seems worth remembering that dozens to potentially hundreds of different kinds of paper products and relevant raw materials required in paper manufacture made up the material flows of the paper trade. Firstly, there were newly produced writing and printing papers in a plethora of different qualities and formats in Europe, usually as white paper but there were also smaller amounts of blue and coloured papers. ${ }^{68}$ These 'fresh' and 'unused'

(eds.), Spinning the Commercial Web. International Trade, Merchants, and Commercial Cities, c. 1640-1939 (Frankfurt a.M.: Lang, 2004); Cátia Antunes, Globalisation in the Early Modern Period. The Economic Relationship between Amsterdam and Lisbon, 1640-1705 (Amsterdam: Aksant, 2004).

66 Annette Caroline Cremer, and Martin Mulsow (eds.), Objekte als Quellen der historischen Kulturwissenschaften. Stand und Perspektiven der Forschung (Cologne: Böhlau-Verlag, 2017); Arjun Appadurai, 'Introduction. Commodities and the Politics of Value', in Arjun Appadurai (ed.), The Social Life of Things. Commodities in Cultural Perspective (Cambridge: Cambridge University Press, 1986), pp. 3-63; Giorgio Riello, 'Things that Shape History. Material Culture and Historical Narratives', in Karen Harvey (ed.), History and Material Culture. A Student's Guide to Approaching Alternative Sources (London: Routledge, 20o9); Anne Gerritsen, and Giorgio Riello (eds.), The Global Lives of Things. The Material Culture of Connections in the Early Modern World (London: Routledge, 2016); Paula Findlen (ed.), Early Modern Things. Objects and their Histories, 1500-1800 (London: Routledge, 2012).

67 John Nerone, 'The History of Paper and Public Space', Media History, 21:1 (2015) pp. 1-7, here: p. 1 .

68 See on this: Émile Joseph Labarre, 'The Sizes of Paper, their Names, Origin and History', in Horst Kunze (ed.), Buch und Papier. Buchkundliche und papiergeschichtliche Arbeiten, Hans H. Bockwitz zum 65. Geburtstag dargebracht (Leipzig: Harrassowitz, 1949), pp. 35-54; Paul Needham, 'Res papirea. Sizes and Formats of the Late Medieval Book', in Peter Rück, and Martin Boghardt (eds.), Rationalisierung der Buchherstellung im Mittelalter und in der frühen Neuzeit (Marburg/Lahn: Institut für Historische Hilfswissenschaften, 1994), pp. 123-145; and Bellingradt, Vernetzte Papiermärkte, pp. 40-66. On coloured and blue papers see introductory: Wisso Weiss, 'Blaues Papier für Druckzwecke', Gutenberg Jahrbuch (1959), pp. 26-35; Irene Brückle, 'The Historical Manufacture of Blue-coloured Paper', The Paper Conservator, 17 (1993), pp. 20-31. 
paper sheets came with the most confusing range of names referring to watermarks, usages, format, quality, and place of manufacture. "This multiplicity of names", as E. J. Labarre put it, reminds paper historians of the varieties of sheets (for writing and printing papers alone) present in the trade. ${ }^{69} \mathrm{As}$ it was very important for contemporary purchasers of writing and printing papers to have an overview of the many paper varieties on offer in the trade, the historian's eye should pay attention when analysing a paper purchase of the past. ${ }^{70}$ Among these newly produced sheets were also many special drawing papers popular among artists, ${ }^{71}$ as well as all sorts and variations of 'brown', 'blue' and 'grey' wrapping and packaging papers, including cardboard and cartons, that were constantly present and traded by paper merchants, and bought from apothecaries by almost all other businesses that needed wrapping for their goods. ${ }^{72}$ Also available on these paper markets were used and old papers from unsold, rejected, or slow-selling books, as well as from ephemeral publications like small pamphlets and cheap newspapers that were systematically sold to customers like fishmongers and grocers, and of course to paper makers in need of this material resource for the manufacture of new paper. ${ }^{73}$ There were also

69 Labarre, 'The Sizes of Paper', p. 35. See further: Karl Theodor Weiss, Handbuch der Was serzeichenkunde, ed. Wisso Weiss (Leipzig: Fachbuchverlag, 1962), pp. 49-57; Tschudin, Grundzüge der Papiergeschichte, p. 100.

70 This topic is present in early modern manuals on the art of printing, see for example: Hieronymus Hornschuch, Orthotypographia, hoc est Instructio operas typographicas correcturiis (Leipzig: Michael Lantzenberger, 1608). A range of layout issues are explained in Philipp Gaskell, A New Introduction to Bibliography, 2nd ed. (Oxford: Clarendon Press, 1974), pp. 84-107.

71 Jane Roberts, A Dictionary of Michelangelo's Watermarks (Milan: Olivetti, 1988); John Krill, English Artists Paper. Renaissance to Regency (London: Trefoil, 1987); Peter Bower, Turner's Papers. A Study of the Manufacture, Selection and Use of his Drawing Papers 1787-1820 (London: Tate Gallery, 1990).

72 A few references on these desiderata can be found here: Diana Twede etc., Cartons, Crates and Corrugated Board. Handbook of Paper and Wood Packaging Paper, 2nd ed. (Lancaster, Penn.: DEStech Publications, 2015); Coleman, The British paper industry, pp. 5-6; Heinz Schmidt-Bachem, Aus Papier. Eine Kultur- und Wirtschaftsgeschichte der Papier verarbeitenden Industrie in Deutschland (Berlin: De Gruyter Sauer, 2011).

73 See Bellingradt, Vernetzte Papiermärkte, pp. 40-66; Leah Price 'Getting the reading out of it. Recycling and repetition in London labour and the London poor'. In: Ina Ferris, and Paul Keen (eds.), Bookish Histories. Books, Literature, and Commercial Modernity, 170o1900 (Basingstoke: Palgrave Machmillan, 2009), pp. 148-168; William St Clair, The Reading Nation in the Romantic Period (Cambridge, Cambridge University Press 2004), esp. p. 28; Caspar Hirschi, and Carlos Spoerhase, 'Kommerzielle Bücherzerstörung als ökonomische Praxis und literarisches Motiv. Ein vergleichender Blick auf das vorindustrielle und digitale Zeitalter', Kodex, 3 (2013), pp. 1-23; Amélie Junqua, 'Eighteenth-century paper. The readers' digest', in Rebecca Anne Barr, Sylvie Kleiman-Lafon, and Sophie Vasset (eds.), 
all sorts of waste papers from printshops (i.e. leftovers, unused and damaged papers from the printing processes) and often even linen rags (as the main textile raw material for the manufacture of new papers). ${ }^{74}$ Because all these paper materials were typical goods of the paper trade business, the historical view ought to highlight these relevant material flows carefully and in detail.

Secondly, the theme 'materials' also highlights the physical story of the commodity paper as a good to be sold in specific trade units. As most paper amounts in early modern Europe were calculated in trade units around quantity, i.e. describing the number of sheets, until the early nineteenth century (when a general change to units of weight began), the current paper trade history needs to shed light more carefully on these (changing) units. Evidence suggests that writing and printing paper was sold as single-sheets, ${ }^{75}$ in units of 5 sheets (called in Spanish, for example, cuadernillo, in French, cahier d'un livre, and in German, Fünferbogen), in units of 24/25 sheets (called for example in Dutch a boek, in German ein Buch, in English "a quire," and in French une main), but the most common trade unit in early modern Europe was the ream - of about 500 sheets of printing paper or 480 sheets of writing paper each. ${ }^{76}$ Originally, this ream (in German and Dutch Riemen, in French reyme, in Spanish resma, in Italian risma) trade unit derived from the Arab word rizmah, meaning nothing more specifically than a bundle or bale, in which the first papers that reached Europe were packed when Arab businessmen traded in the twelfth and

Bellies, Bowels and Entrails in the Eighteenth Century (Manchester: Manchester University Press, 2018), pp. 128-144; and the chapter by Anna Reynolds in this volume.

74 Labarre, 'The Sizes of Paper', p. 39. See exemplary on the early modern Dutch trade in shredded papers of different qualities: Bellingradt, 'Paper Networks'; Bellingradt, Vernetzte Papiermärkte, pp. 153-169; and soon the PhD dissertation by Sandra Zawrel (Erfurt).

75 On single sheets selling see Heather Wolfe, Was early modern writing paper expensive?, https://collation.folger.edu/2018/o2/writing-paper-expensive/ (13.02.2018, last accessed 04.05.2020). More evidence of these small purchases can be found, for example, in Laurie E. Maguire, 'The Craft of Printing (16oo)', in Kastan, A Companion to Shakespeare, pp. 434449, esp. 434; Paul Davis, 'Popery and Publishing in the Restoration Crisis. A Whig Gentry Family's Credit Account with their London Bookseller, 168o-1683', The Library, 15:3 (2014), pp. 261-291, esp. p. 264; Howard M. Nixon, 'The Memorandum Book of James Coghlan. The Stock of an 18th-Century Printer and Binder', Journal of the Printing Historical Society, 6 (1970) pp. 34-52, esp. p. 34.

76 See "Ream" in: Émile J. Labarre, Dictionary and encyclopaedia of paper and paper-making with equivalents of the technical terms in French, German, Dutch, Italian, Spanish and Swedish, 2nd ed. (Amsterdam: Swets \& Zeitlinger, 1952), p. 222. Depending on the quality of the paper, the sheets in a ream differed between $472,480,504$ or 516 , sometimes referred to as vaguely a "short ream" or "long ream." In Europe, only the German equivalent of a "Ream" is not a unit for about 5 oo sheets. The German "Riemen“ comprises around 5000 sheets of paper; a German „Ries“ of 500 sheets is the international "ream.” 
thirteenth century along the Mediterranean coast. Remembering this original inexact category for trading paper is important, because calculating the early modern paper trade is and was a tricky business that requires special material attention. Generally, some of the trade units used remain mysterious, as we do not yet have sufficient and comparable details on them. For example, among the variety of units used within the German paper trade in Hamburg - Partie, Pack(en), Ballen, Kiste, Riem(en), Bund, Stuck, Ries, Kiste, Faß, Koffer, Parcel, Bündel, Buch and Sack - we only have detailed information on Riem (about 50oo sheets), Ries (about 5 oo sheets) and Buch (24 or 25 sheets). ${ }^{77}$ Among the difficulties in calculating the trade units are the changing relations of same trade units even used at the same places but at different times. Locally used terms and scales could differ radically within a few years or decades, therefore paper trade history needs to engage in more detail with what exactly was traded within a focused moment of time. For example, and to further explore the exemplary case of Germany, in Hamburg the proportion between a Ballen (bale) and a Riem (ream) changed in Hamburg from 1:1 to 1:5 between 1782 and 1808 - a difference of 20,000 sheets. During the sixteenth and seventeenth centuries, the definition of a German Ballen within the Holy Roman Empire could easily differ by 1,000 sheets depending on the place of trade. ${ }^{78}$ The German Ballen was sometimes an equivalent of the German Riemen (about 5000 sheets), while a Spanish Balón was a unit comprising around 10,000-12,000 sheets of paper, and a Dutch Ballen had 10,00o sheets, packed into 21 Dutch Riemen (the same as a Dutch Fass, barrel, or Korb, basket, also of about 10,000 sheets, by the way). ${ }^{79}$ In short, trade unit calculations need special material attention to the following factors: the quality and format of the paper traded; the amount of paper sheets that were traded; the time of trade transaction; the involved actors (buyer and seller) and their local usances of defining a trade unit. As early modern paper merchants were quite accurate when it came to understanding and defining the trade units used within Europe, and we have evidence of this detailed "trade unit knowledge" and its inherent material sensitivity ${ }^{80}$ this accuracy should be mirrored within paper trade history.

\footnotetext{
77 Bellingradt, 'Trading paper'.

78 Thiel, 'Papiererzeugung und Papierhandel', p. 128.

79 The calculation ratio for "Fass" and „Korb" into Dutch Ream (of about 5 oo sheets) are taken from the STRO database (URL: http://www.soundtoll.nl/index.php/en/over-het-project/ str-online). On this database see the chapter by Jan-Willem Veluwenkamp in this volume.

80 An insider view of the perceived plurality of paper products on the early modern markets for papers is, for example, the Memorie der Papier-Negotie naer Experientie, a. 1781 ("Account of the paper trade according to experience, a. 1781" (Gemeentearchief Zaanstad,
} 
Thirdly, the costs and prices of the materials of the paper trade require more attention. Building on the increased attentiveness to the plurality of paper products and raw materials traded on the early modern markets for paper, a closer focus on valuations becomes important. As soon as we know the exact paper material traded and its prices, investigations into the yet unknown market dynamics of preparation costs, availability, and selection by purchasers are opened up. Making sense of the costs of manufacture, the purchasing conditions, and the needs and criteria of paper buyers depends upon more research into the prices of paper products and the costs of these transactions between the mills and the traders, as well as the end-sellers and the final purchasers. The problem of unearthing a set of comparable prices for the various paper products make it nearly impossible to calculate paper costs seriously (or at all) at present. ${ }^{81}$ As a reminder: the prices that we sometimes find in paper trade related sources are the payments that one party (the buyer) gives to another (the seller) in return for a specific unit of a paper good. Mentioning these prices, however, is only the first step to making sense of the costs and prices of the paper trade. A price only acquires meaning when you compare it to other goods traded at the same moment (other paper products and other products in general), therefore collecting prices leads to a relational access to the paper trade economy and its markets. In this light, the existing data on costs and prices of paper, and the interpretation of these factors, are still too sketchy. Even the tentative calculations already made for expenditures on paper by an early-modern printing workshop range between 20 and 70 percent of the total production costs. ${ }^{82}$ But, while it is true that paper was one of the most expensive elements of book production during the hand-press era, we should also consider the paper not used in a printing office. The prices of paper sheets purchased in small amounts - for example in single sheets of writing paper indicate a very different story of paper purchases. As Heather Wolfe and others have pointed out, purchasing single sheets and small amounts of paper was not that expensive and quite normal, as a deeper look into the accounts[?] of

PA 451, inv. 2406, unfol.) written by a paper trader. This account is also mentioned in the chapter by Andreas Weber.

81 On the problems of calculating historical prices: see Mark Spoerer, 'Price Data as a Historical Source', in Kypta, Bruch, Skambraks, Methods in Premodern Economic History, pp. 105-106.

82 See the details presented in section II of this introduction and for a range of references and estimates on costs and prices from the sixteenth to the eighteenth centuries see: Bellingradt, Vernetzte Papiermärkte, pp. 82-84. 
book shops demonstrates. ${ }^{83}$ As we know that booksellers systematically dealt with all sorts of paper products, fresh and used, damaged and functioning, printed and non-printed upon, this material story of selling - and of prices for certain objects - should be featured more frequently and prominently in book history. Also, knowing the prices and costs of manufacture, as well as of storage and transport, are helpful when it comes to deciphering the decisions about materials made by publishers for particular paper publications. With more data on prices and costs, the purchasing strategies and determinations of early modern European publishing industries could be better understood. In fact, book historical interpretations of how and when a 'physical book' takes material and intellectual shape, as has been put forward, for example, in the so-called 'archaeology of the book', ought to be connected to the contemporary availability and the prices of paper offered on the market. ${ }^{84}$

A material focus also explores the physical conditions of the trade and transport of paper goods in early modern Europe. Paper did not just 'travel' on its own to different destinations, but was moved by people from the mills to warehouses, apothecaries, print shops, and many more places of buying and (re-)selling. A nuanced paper history should investigate the materiality of these movements, as well as where they break down, in more detail. In fact, the material details of the shipments of paper commodities by boat and wagon are largely unknown, as are the locations and material conditions of the places of storage of paper products. We are in need of studying the physical ins-and-outs of paper in order to write a material story of the commodity and its trade within Europe. Who transported, sold, and bought paper? Who stored it under which material conditions? Where? And, who re-sold it again?

83 See exemplary: Stevens, Gehl, 'Giovanni Battista Bosso'; Kevin M. Stevens, and Paul F. Gehl, 'Cheap Print. A Look inside the Lucini-Sirtori Stationery Shop at Milan (1597-1613)', La Bibliofilía, 112 (2010), pp. 281-327; Steven van Impe, "SChrijf-papieren van diversche groote en qualitijten". De papierwinkel van P. J. Parys in achttiende-eeuws Antwerpen', Jaarboek voor Nederlandse boekgeschiedenis, 21 (2014), pp. 135-154; Jason McElligott, 'The Book Trade, Licensing, and Censorship', in Laura Lunger Knoppers (ed.), The Oxford Handbook of Literature and the English Revolution (Oxford: Oxford University Press, 2012), pp. 135153; Arianne Baggerman, Publishing Policies and Family Strategies. The Fortunes of a Dutch Publishing House in the 18th and Early 19th Centuries (Leiden: Brill, 2014), esp. pp. 104-108.

84 This claim has been made by Carlo Federici ('Sul Fallimento dell'Archeologia del Libro', Gazette du Livre Médieval, 45 (2004), pp. 50-55) but is not reflected in the main approaches on this topic, as can be seen in Martin Boghardt, Archäologie des gedruckten Buches, ed. Paul Needham (Wiesbaden: Harrassowitz, 2008); Ulrike Gleixner etc. (eds.), Biographien des Buches (Göttingen: Wallstein, 2018). 
While a focus on 'practices' already lays visible the human interconnections of the trade, the theme of networks expands further on this topic. A focus on networks sets out to highlight systems and patterns of activities making visible a larger paper economy. This larger paper economy is accessed via a broad social perspective on those actors dealing with the plurality of paper products on the paper markets. As every actor had its own network of buying and selling paper, a network perspective opens a systematic interpretation of paper flows within a paper economy. In doing so, the markets of paper manufacture can be linked through economic networks of paper traders to the purchases of the print industries and civic administrations, and to the collecting, storing and selling of linen rags and waste paper back to paper manufactures. It is time to explore the close relationships between paper mills, paper warehouses, printing offices, and administration offices in more detail and interpret these connections as networked economies. Also, financing networks should be systematically highlighted and integrated into our understanding of the functioning of a paper economy as they played important roles at the manufacturing stage and often in the supply of 'reams on contract' to certain paper traders. ${ }^{85}$ For example, it was a common commercial pattern for Amsterdam merchants to be financially involved (as a partner or co-owner in a "Compagnieschap voor de handel in papier") in Dutch and other European paper mills. ${ }^{86}$ In order to define and investigate common characteristics of those networks involved in the paper trade, the concept of sociality (of the paper trade) may be helpful. ${ }^{87}$ In recent historiography, the term sociality is used to refer to the collective

85 See for example the French paper mills of Angoulême which were partly owned by Dutch merchants: Leonard N Rosenband, Papermaking in eighteenth-century France. Management, labor, and revolution at the Montgolfier Mill 1761-1805 (Baltimore: Johns Hopkins University Press, 200o); Henk Voorn, 'Amsterdam en Angoulême. En bijdrage tot de geschiedenis van de Frans-Nederlandse papierhandelsbetrekkingen', Papierwereld, 19:11 (1965), pp. 407-417.

86 Van Eeghen, De Amsterdamse Boekhandel, v., chapter „Papierhandel“ (pp. 195-272), has looked upon aspects of the paper trade economy in her survey article on the „Boekhandel van de republiek, 1572-1795“ (van Eeghen, De Amsterdamse Boekhandel, v. 11-128). There is a section on the trade customs of this economy, pp. 34-39, offering a broad view on the financial interwovenness of the paper production and trade with the general Dutch mercantile activity. Also: Robert S. Duplessis, 'Capital and Finance in the Early Modern Veluwe Paper Industry', AAG Bijdragen, 28 (1986), pp. 185-197; Voorn, De geschiedenis der Nederlandse papierindustrie, I.; Henk Voorn, 'Uit de oudste geschiedenis van de Amsterdamse papierhandel. In het bijzonder over de Compagnie der Duytse papieren', Prikkels, 303 (1967), pp. 6-28, esp. 13f.; More examples and more literature of financial companies that run paper mills can be found in: Bellingradt, Vernetzte Papiermärkte.

$87 \quad$ On the tradition and usefulness of positioning early modern actors and their networking practices within larger economic activities: Blondé et al., Buyers \& Sellers. 
actions of a specific group located within time and space. ${ }^{88}$ As research on the sociality of early modern economic networks has demonstrated, the fundamental question regarding paper trade networks should be, "who did what exactly (and why) for how long and with whom?'89 Building on ideas presented in market sociology and economic sociology, the markets for the trade of paper may be understood and interpreted as social figurations allowing an interactionist analysis of economic cooperation and activities. ${ }^{90}$ These models have been introduced influentially within early modern economic history in recent years, and connecting with this trend may be another benefit for a history of the paper trade..$^{91}$

A Future Paper History

A future paper history benefits from a deeper engagement with the three themes of this edited volume, the practices, materials, and networks of the

88 On the usage of 'sociality'/'sociability' in historical approaches see: Maurice Agulhon, 'Introduction. La sociabilité est-elle objet d'histoire?', in Étienne François (ed.), Sociabilité et société bourgeoise en France, en Allemagne et en Suisse 1750-1850 (Paris: Édition Recherche sur les Civilisation, 1986), pp. 13-23; Susanne Rau, Räume der Stadt. Eine Geschichte Lyons, 1300-1800 (Frankfurt a.M.: Campus-Verlag, 2014), pp. 46-51.

89 Simon Teuscher, Bekannte, Klienten, Verwandte. Soziabilität und Politik in der Stadt Bern um 1500 (Cologne: Böhlau, 1998), p. 1. For network perspectives within economic history of early modern Europe: Andrea Caracausi, and Christof Jeggle, 'Introduction', in Andrea Caracausi, and Christof Jeggle (eds.), Commercial Networks and European Cities, 1400-1800 (London: Pickering \& Chatto, 2014), pp. 1-12, esp. pp. 1-5; Paul D. McLean, The Art of the Network. Strategic Interaction and Patronage in Renaissance Florence (Durham, NC: Duke University Press, 2007), pp. 1-33.

90 On economic sociology: Mauro F. Guillén etc. (eds.), The New Economic Sociology. Developments in an Emerging Field (New York: Russell Sage Foundation, 2002); Mark Granovetter, and Richard Swedberg (eds.), The Sociology of Economic Life, 2nd ed. (Boulder, Col.: Westview Press, 2001); Richard Swedberg, Principles of Economic Sociology (Princeton: Princeton University Press, 2003). On market sociology: Jens Beckert, Rainer Diaz-Bone, and Heiner Ganßmann (eds.), Märkte als soziale Strukturen (Frankfurt a.M.: Campus-Verlag, 2007); Patrik Aspers, 'Sociology of Markets', in Jens Beckert, and Milan Zafirovski (eds.), International Encyclopedia of Economic Sociology (London: Routledge, 2006), pp. 427-432.

91 See Christof Jeggle, 'Die Konstituierung von Märkten. Soziale Interaktion, wirtschaftliche Koordination und materielle Kultur auf vorindustriellen Märkten', Annales Mercaturae, 2 (2016), pp. 7-32; Christof Jeggle, 'Merchant Communities, Commercial Networks, and the Constitution of Markets', in Georg Christ etc. (eds.), Union in Separation. Diasporic Groups and Identities in the Eastern Mediterranean (1100-1800) (Rome: Viella, 2015), pp. 571-592. See my new book (Bellingradt, Vernetzte Papiermärkte) as a first attempt to connect paper history with market sociology and economic history alike. 
paper trade. Integrating the trade of the good 'paper' into the many paper usages of the period is necessary and looming within European research activities on the matter. The highlighting of practices and network activities offers the historical interpretation a bird's-eye view on the patterns of paper flows within a larger paper economy. When the analysis follows the material flows that are necessary for manufacturing paper, it sheds light on the moments and rhythms of movement of the new paper products from place to place, pays attention to the storing and (re-)selling of these paper materials, notes the usages of paper for communication and wrapping purposes, and then also highlights the material flows back to the paper manufacturers. Thus, the bigger picture of a circular paper economy emerges. A meta-level observation builds fundamentally on the ways that material may escort the views of historical storytelling, as was mainly developed and used in histories of mobilities, circulation and transport logistics. ${ }^{92}$ Such a focus on the material flows of the paper trade can be found in so-called "it narratives" of the eighteenth century and in recent object biographies thriving in many interdisciplinary fields. ${ }^{93}$ By describing the historical contexts of the paper trade as a connected economic sector in which necessary materials of the paper markets were manufactured, traded, stored, sold, bought, used, re-used and finally recycled by a numerous range of cooperating actors and networks, a larger textile, rags, and

92 See on the meta-narrative of "material flows" in current history: Monika Dommann, "Alles fließt. Soll die Geschichte nomadischer werden?', Geschichte und Gesellschaft, 42 (2016), pp. 516-534; Monika Dommann, 'Handling, Flow Charts, Logistik. Zur Wissensgeschichte und Materialkultur von Warenflüssen', in David Gugerli etc. (eds.), Nach Feierabend 2011. Zirkulationen (Zürich: Diaphanes, 2011), pp. 75-103; Stefanie Samida, Manfred K.H. Eggert, and Hans Peter Hahn (eds.), Handbuch Materielle Kultur. Bedeutungen, Konzepte, Disziplinen (Stuttgart: Metzler, 2014); Lissa L. Roberts, and Simon Werrett (ed.), Compound Histories. Materials, Governance and Production, 1760-1840 (Leiden: Brill, 2017); Christopher Tilley et. al.. (eds.), Handbook of Material Culture (London: SAGE Publishing 2006).

93 On 'it-narratives' see the British examples in Mark Blackwell (ed.), The Secret Life of Things. Animals, Objects, and It-Narratives in Eighteenth-Century England (Lewisburg: Bucknell University Press, 2007). There is also an edition of these published, it narratives' by Mark Blackwell (British It-Narratives, 1750-1830 (4 vols., London: Pickering \& Chatto, 2012) in which 'Adventures of a Quire of Paper' can be found (IV. 23-39). See on this paper "adventure" further: Ariane Fennetaux, "Sentimental Economics. Recycling Textiles in Eighteenth-Century Britain', in Ariane Fennetaux, Amèlie Junqua, and Sophie Vasset (eds.), The Afterlife of Used Things. Recycling in the Long Eighteenth Century (New York: Routledge, 2014), pp. 122-141; Bellingradt, Vernetzte Papiermärkte, pp. 111-135. On object biographies see Appadurai, The Social Life of Things; Thierry Bonnot, La vie des objets. D'utensils banals á objects de collection (Paris: Édition de la Maison des Sciences de l'Homme, 2002); Janet Hopkins, 'Agency, Biography and Objects', in Tilley etc., Handbook of Material Culture, pp. 74-84. 
paper economy becomes visible. This circular 'paper economy' is much more than just a supplemental aspect of an alleged "age of print" of early modern Europe, as it has been influentially characterized in the last decades by media and book historians alike. In fact, a broad to-be-designed paper history of early modern Europe is an alternative master narrative for the epoch in question. Future investigations into this first paper age of Europe, lasting from the early fourteenth to the early nineteenth centuries, calls for even more academic alliances than economic history, book history, market sociology, and communication history are offering at the moment. As every early modern paper manufacturer only thrived when textile industries were nearby, a future paper history should interact more closely with environmental history and the history of textile industries. ${ }^{94}$ The trade of rags - the rag flows among the material flows of the paper markets - remains one of the biggest desiderata of the field. When it comes to the material resources of the paper industry, linen rags are as understudied as a traded good, as indeed waste papers of all sorts are. In developing recycling perspectives on the reusages of papers and textiles alike, a future paper history will help establish a more concise view on yet unseen economic practices and alliances. ${ }^{95}$ The impact of a future paper history that pays attention to the materiality of the traded goods and the trade itself, that focuses more closely on the involved actors and their practices and network activities, might be seen in a couple of years in many interdisciplinary fields concerned with early modern Europe. With this volume, paper history takes a first step into this future.

94 See introductory: Dieter Schott, Bill Luckin, and Geneviève Massard-Guilbaud (eds.), Resources of the City. Contributions to an Environmental History of Modern Europe (Burlington: Ashgate, 2005).

95 See for example the chapter by Anna Reynolds in this volume. Also: Fennetaux, Junqua, Vasset (eds), The Afterlife of Used Things. 